\title{
Drying kinetics and thermodynamic properties of boldo leaves (Plectranthus barbatus Andrews)
}

\section{Cinética de secagem e propriedades termodinâmicas de folhas de boldo (Plectranthus bardatus Andrews)}

\author{
Naiane Cristina Braga da SILVA'; Samuel Gonçalves Ferreira dos SANTOS ${ }^{2}$; Daniel Pereira da SILVA ${ }^{3}$; \\ Isneider Luís SILVA ${ }^{4}$; Renato Souza RODOVALHO ${ }^{5}$ \\ ${ }^{1}$ Acadêmica do curso de Agronomia, Instituto Federal Goiano - Campus Ceres, naiane.nnanny@hotmail.com \\ ${ }^{2}$ Autor para correspondência, Acadêmico do curso de Agronomia, Instituto Federal Goiano - Campus Ceres, \\ samuel-2100@hotmail.com \\ ${ }^{3}$ Acadêmico do curso de Agronomia, Instituto Federal Goiano - Campus Ceres, danielsilva.agron@gmail.com \\ ${ }^{4}$ Mestrando em Engenharia Agrícola, Universidade Estadual de Goiás-Anápolis, GO, isneiderrr@hotmail.com \\ ${ }^{5}$ Doutor em Agronomia, IF Goiano - Campus Ceres, renato.rodovalho@ifgoiano.edu.br
}

Recebido em: 09-03-2018; Aceito em: 19-11-2018

\begin{abstract}
Boldo leaves are used as medicinal plants by the Brazilian population. Among several factors that contribute to the proper storage of this product, we highlight the drying process, which is fundamental to reduce its moisture content, aiming to maintain phytotherapic characteristics. Different works involving the drying of leaves were carried out in the last years. However, there is not much information related to the drying process related to boldo leaves. This work evaluates drying kinetics at temperatures of 20,40 and $60^{\circ} \mathrm{C}$, as well as determines thermodynamic properties: enthalpy, entropy and Gibbs free energy. Forced air circulation ovens were used for thin layer drying of leaves. The leaves, uniformly cut rectangular, were weighed periodically until hygroscopic equilibrium. Several mathematical models were fitted to the experimental data to characterize the drying processes, using the following statistical criteria: coefficient of determination $\left(\mathrm{R}^{2}\right)$, mean standard error $(\mathrm{SE})$, chi-square $\left(\mathrm{X}^{2}\right)$, and residue distribution. According to the criteria used, Modified Henderson and Pabis was the model that best represented the drying kinetics of boldo leaves. The activation energy for the drying of boldo leaves was $17.969 \mathrm{~kJ} \mathrm{~mol}^{-1}$. Both enthalpy and entropy decreased with increasing drying air temperature, while Gibbs free energy increased.
\end{abstract}

Additional keywords: activation energy; enthalpy; medicinal plants.

\begin{abstract}
Resumo
As folhas de boldo são utilizadas como plantas medicinais pela população brasileira. Dentre vários fatores que contribuem para o armazenamento adequado deste produto, destaca-se a secagem, que consiste em um processo fundamental para reduzir seu teor de água, visando à manutenção de suas qualidades fitoterápicas. Diferentes trabalhos envolvendo a secagem de folhas foram realizadas nos últimos anos. Entretanto, não há muitas informações relacionadas ao processo de secagem referente a folhas de boldo. $O$ objetivo neste trabalho foi avaliar a cinética de secagem nas temperaturas de 20,40 e $60^{\circ} \mathrm{C}$, bem como determinar suas propriedades termodinâmicas: entalpia, entropia e energia livre de Gibbs. Foram utilizadas estufas de ventilação forçada para 0 processo de secagem das folhas em camada delgada. As folhas, recortadas uniformemente de forma retangular, foram pesadas periodicamente até o alcance do equilíbrio higroscópico. Vários modelos matemáticos foram ajustados aos dados experimentais para caracterizar os processos de secagem, utilizando critérios estatísticos: coeficiente de determinação $\left(R^{2}\right)$, erro médio estimado (SE), qui-quadrado $\left(X^{2}\right)$ e a distribuição de resíduos. De acordo com os critérios utilizados, o modelo de Henderson e Pabis Modificado foi o que melhor representou a cinética de secagem das folhas de boldo. A energia de ativação para a secagem das folhas de boldo foi de $17,969 \mathrm{~kJ} \mathrm{~mol}^{-1}$. Tanto a entalpia quanto a entropia reduziram com o aumento da temperatura do ar de secagem, enquanto a energia livre de Gibbs obteve aumento.
\end{abstract}

Palavras-chave adicionais: energia de ativação; entalpia; plantas medicinais.

\section{Introduction}

Medicinal and aromatic plants are the main raw material for a large number of food, cosmetic, and pharmaceutical industries. The use of medicinal plants is very widespread among the Brazilian population, with several factors contributing to the development of health practices, including the low cost of home medi- cine and the therapeutic properties derived from active principles (Martins et al., 2015).

Among the several species of medicinal plants known in Brazil, Boldo (Plectranthus bardatus Andrews) is widely cultivated in botanical gardens and home gardens in the east and southeast of Brazil. Its leaves are used in the treatment of various digestion related diseases (Lorenzi \& Matos, 2002), and com- 
prise several alkaloids, the main one being boldine. This alkaloid is responsible for increased bile secretion, which is a substance produced in the liver to aid in the digestion of fats (Grandi et al., 1989).

Most medicinal plants are commercially supplied in the dried form, thus increasing the practice of drying. This practice, which includes boldo leaves, is essential for the longevity and quality of products. Drying appears as the process most used to extend the useful life of medicinal plants, as it guarantees stability during storage (Santos et al., 2013). It consists of the removal of much of the water initially contained in the product just after physiological maturity, promoting long storage periods without significant losses during the process (Sousa et al., 2015).

Drying kinetics is an analysis of the mass transfer behavior between foliar tissues and the drying agent. It contributes to information about the behavior of the plant product during the process, further providing information for simulation, equipment sizing, and determining thermodynamic properties involved between the plant product and the drying air.

Knowledge of the thermodynamic properties in the drying processes of agricultural products also constitutes an important source of information to calculate the required energy, to study the properties of the adsorbed water, and to evaluate the food microstructure and the physical phenomena that occur on its surface (Corrêa et al., 2010).

Different works involving the drying of leaves were carried out in the last years, as: Drying of leaves of whale grass (Cordia verbenacea DC.) (Goneli et al., 2014a); Drying of basil leaves (Reis et al., 2012); drying of leaves of Ziziphus joazeiro Mart (Sousa et al., 2015). However, the drying of the boldo leaves in their integral form has not yet been performed, nor the determination of their thermodynamic properties. Thus, there is a lack of information to calculate the energy required for the drying process to occur in relation to this product.

The enthalpy changes provide a measure of the energy variation that occurs in the interaction of the water molecules with the constituents of the product during the sorption processes. Entropy is associated with the binding or repulsion of the water molecules of food components in the system and is associated with the spatial arrangement of the water product relationship (Oliveira et al., 2015). Therefore, entropy characterizes the degree of order or disorder. The Gibbs free energy can indicate how much water is bound to the product, besides providing an evaluation criterion on the removal of this fluid (Araujo et al., 2017). In this context, the Gibbs free energy represents the affinity of the leaf for the water as it is the energy required for the transfer of the water molecules in a vapor state to the air or to the leaves (Corrêa et al., 2010).

In view of the above, the present work evaluates the drying kinetics of boldo leaves, at temperatures of 20,40 and $60^{\circ} \mathrm{C}$, and determines its thermodynamic properties: enthalpy, entropy and Gibbs free energy.

\section{Materials and methods}

Boldo leaves were randomly collected in regions close to the Instituto Federal Goiano - Campus Ceres. The collection was performed in the first hours of the morning, after the dew has dried, to avoid variations in the initial moisture content. 50 leaves were then selected and transported to the Plant Physiology Laboratory of Campus Ceres, where the experiment was conducted.

The initial moisture content and equilibrium of the samples was determined after product selection and at the end of the drying, by gravimetric method in a forced-air circulation oven at $103 \pm 1{ }^{\circ} \mathrm{C}$ for $24 \mathrm{~h}$, with three replicates, for each drying temperature studied (ASABE, 2010).

The selected leaves were subjected to three temperatures in a forced-air ventilation oven: 20,40 and $60{ }^{\circ} \mathrm{C}$. Drying air temperature was monitored by a mercury thermometer. The relative humidity inside the oven was calculated using Grapsi ${ }^{\circledR}$ software, based on the external environment conditions, also monitored during the drying process by using a psychrometer.

The samples were cut rectangularly and deposited in non-perforated plastic trays with $2.2510^{-2} \mathrm{~m}^{2}$ to form a thin layer in each repetition during drying. At the beginning of the drying process, $35 \mathrm{~g}$ of samples were placed in 4 replicates and weighed periodically until constant mass. At the end of drying, the samples were subjected to the determination of moisture content on a dry basis. Subsequently, the moisture content ratio (MR) during the drying processes was calculated by equation 1 .

$M R=\frac{\left(X-X_{e}\right)}{\left(X_{i}-X_{e}\right)}$

In which: $\mathrm{X}$ - Moisture content of the product, decimal (d.b.).; $X_{i}$-initial water content of the product, decimal (d.b.); $X_{e}$-equilibrium water content of the product, decimal (d.b.).

After the drying process, mathematical models were used (Table 1) to fit the experimental data obtained.

In the selection of the best models, to represent the drying kinetics of boldo leaves, the following were considered: significance of the regression coefficients by the $\mathrm{T}$ test, adopting a $5 \%$ significance level; magnitude of the determination coefficient adjusted by the model $\left(R^{2}\right)$; mean standard error (SE) (Equation 2); chi-square test $\left(x^{2}\right)$ (Equation 3); and residue distribution. For the recommendation of the mathematical model of drying kinetics, we considered the $\mathrm{R}^{2}$ closest to the unit, with the lowest SE value. The lowest $x^{2}$ value calculated among the models was obtained according to the level of significance $(\alpha=0.05)$ and the number of degrees of freedom (NDF). Residue behavior was considered random when observing a uniform distribution between the residue axes and the drying period. 
$\mathrm{SE}=\sqrt{\frac{\sum_{\mathrm{i}=1}^{\mathrm{n}}(\mathrm{Y}-\widehat{\mathrm{Y}})^{2}}{\mathrm{NDF}}}$

$X^{2}=\sum_{i=1}^{n} \frac{(Y-\widehat{Y})^{2}}{N D F}$
In which: SE - mean standard error; $\mathrm{n}$ - number of cases; $Y$-experimental value; $\hat{Y}$-estimated value; NDF - degree of freedom of the model (number of experimental observations less the number of coefficients of the model); $x^{2}-$ chi-square.

Table 1 - Adjust models for the experimental data of moisture content ratio (MR) as function of drying.

\begin{tabular}{llc}
\hline Model name & \multicolumn{1}{c}{ Model } & $\mathrm{n}$. \\
\hline Diffusion approximation & $\mathrm{MR}=\mathrm{a} \exp (-\mathrm{kt} \mathrm{t})+(1-\mathrm{a}) \exp (-\mathrm{k} \mathrm{b} \mathrm{t})$ & $(4)$ \\
Two terms & $\mathrm{MR}=\mathrm{a} \exp (-\mathrm{k} \mathrm{t})+\mathrm{b} \exp (-\mathrm{k} 1 \mathrm{t})$ & $(5)$ \\
Logarithm & $\mathrm{MR}=\mathrm{a} \exp (-\mathrm{k} \mathrm{t})+\mathrm{b}$ & $(6)$ \\
Newton & $\mathrm{MR}=\exp (-\mathrm{kt} \mathrm{t}$ & $(7)$ \\
Exponential of two terms & $\mathrm{MR}=\mathrm{a} \exp (-\mathrm{k} \mathrm{t})+(1-\mathrm{a}) \exp (-\mathrm{k}$ a t) & $(8)$ \\
Modified Handerson and Pabis & $\mathrm{MR}=\mathrm{a} \exp (-\mathrm{k} \mathrm{t})+\mathrm{b} \exp (-\mathrm{k} 1 \mathrm{t})+\mathrm{c} \exp (-\mathrm{k} 2 \mathrm{t})$ & $(9)$ \\
\hline
\end{tabular}

In which: MR - moisture content ratio, addimentional; $\mathrm{t}$ - drying time, hour; $\mathrm{k}$ - drying coefficient; a, b, c, n, k, k1, k2 - constants of models.

The effective diffusion coefficient (Deff) (Equation 10) was obtained by fitting the liquid diffusion model of flat plate geometry to the experimental data of drying, with the approximation of 8 terms. Boldo leaf thickness was measured using a pachymeter to obtain a mean for use in the model.

$\mathrm{MR}=\frac{X-X_{e}}{X_{i}-X_{e}}=\frac{8}{\pi^{2}} \sum_{n=1}^{\infty} \frac{1}{(2 \cdot n+1)^{2}} \cdot \exp \left[-\frac{(2 \cdot n+1)^{2} \cdot \pi^{2} \cdot D_{\text {eff }} \cdot t}{4}\left(\frac{S}{V}\right)^{2}\right](10)$

In which: MR - moisture content ratio (dimensionless); $X$ - water content of the grain (d.b.); $X_{i}-$ initial water content of the grain (d.b.); $X_{e}$-equilibrium water content of the grain (d.b.); $D_{\text {eff }}$ - effective diffusion coefficient $\left(\mathrm{m}^{2} \mathrm{~s}^{-1}\right) ; \mathrm{n}$ - number of cases (terms); $\mathrm{t}$ - time (s).

The relationship between the effective diffusion coefficient (Deff) and the drying air temperature was described by the Arrhenius model (Equation 11).

$D_{\text {eff }}=D_{0} \exp \left[-\frac{E_{a}}{R \cdot T_{a}}\right]$

In which: $D_{0}$ - pre-exponential factor $\left(\mathrm{m} \mathrm{s}^{-1}\right)$; $E_{a}$ - activation energy $\left(\mathrm{J} \mathrm{mol}^{-1}\right) ; \mathrm{R}$ - universal gas constant, $8.314 \mathrm{~J}(\mathrm{~mol} \mathrm{~K})^{-1} ; \mathrm{T}_{\mathrm{a}}-$ absolute temperature $(\mathrm{K})$.

Thermodynamic properties (specific enthalpy, specific entropy, and Gibbs free energy) related to the drying process of boldo leaves were determined using the method described by Jideani \& Mpotokwana (2009).

$\Delta \mathrm{H}=\mathrm{E}_{\mathrm{a}}-\mathrm{RT} \mathrm{T}_{\mathrm{a}}$

$\Delta S=R \cdot\left[\ln \left(D_{0}\right)-\ln \left(\frac{k_{B}}{h_{P}}\right)-\ln \left(T_{a}\right)\right]$

$\Delta \mathrm{G}=\Delta \mathrm{H}-\mathrm{T}_{\mathrm{a}} \Delta \mathrm{S}$

In which: $\Delta \mathrm{H}$ - enthalpy $\left(\mathrm{J} \mathrm{mol}^{-1}\right) ; \Delta \mathrm{S}$ - entropy $\left(\mathrm{J} \mathrm{mol}^{-1}\right)$; $\mathrm{K}_{\mathrm{B}}$-Boltzmann constant $\left(1.3810^{-23} \mathrm{~J} \mathrm{~K}^{-1}\right)$; $\mathrm{h}_{\mathrm{P}}$ - Planck constant $\left(6.62610^{-34} \mathrm{~J} \mathrm{~s}^{-1}\right)$.

\section{Results and discussion}

Note that for most of the fitted experimental data, the coefficients of determination $\left(R^{2}\right)$ were greater than or close to 0.90 (Table 2). In general, the Modified Henderson and Pabis model was the one that showed high values of the coefficient of determination $\left(R^{2}\right)$ (between 0.90 and 0.99 ) for all treatments. Notwithstanding, according to Madamba et al. (1996), the coefficient of determination $\left(\mathrm{R}^{2}\right)$ alone does not constitute a good criterion for the selection of nonlinear models. Thus, the mean standard error (SE) and the chisquare test $\left(\mathrm{X}^{2}\right)$ were used. According to Siqueira et al. (2012), the lower the SE values, the better the fit of the model to the observed data.

From the analysis of SE and $X^{2}$, it was possible to notice for the temperatures under study that the Modified Henderson and Pabis model was the one that presented smaller values, followed by the two terms model and the diffusion approximation model. Regarding residue behavior, the Modified Henderson and Pabis model and Logarithm presented random distribution for all temperatures (Table 2, Figure 1). The Newton model, in turn, showed biased distribution for all temperatures (Figure 2). In this way, Modified Henderson and Pabis was chosen to represent the drying kinetics of boldo leaves.

Table 3 shows the parameters used for the adjustment of the Modified Henderson and Pabis model, significant at $5 \%$ probability by the t test, for the drying of the boldo leaves. It can be seen that the values of "a", "k1" and "k2" increased, while the values of "k", "b" and "c" decreased with increasing drying air temperature. Among the parameters analyzed, the parameters of "b" and "k2" showed a clear tendency regarding the temperature variation. According to Onwude et al. (2016) the Modified Henderson and Pabis model is derived from Fick's second diffusion law. Parameter "a" indicates the last part of the drying process for food and agricultural products, parameter "b" indicates the intermediate period between the initial and final drying process, and parameter "c" indicates 
the reduction of water during the process. The values of $\mathrm{k}, \mathrm{k} 1$ and $\mathrm{k} 2$ are drying constants. The increase of "k1" and "k2" may be related to the effect of the external drying conditions, since the values of these coefficients characterize the effect of the temperature, which in turn, is related to the effective diffusivity in the drying process for the decreasing period, with diffusion controlling the process. Goneli et al. (2014b), who worked with aroeira leaves, also obtained Modified Henderson and Pabis as the best model to describe the drying kinetics.

Table 2 - Adjusted determination coefficients values $\left(R^{2}\right)$, standard error $(S E)$, chi-square test $\left(X^{2}\right)$, and residues distribution (Dist) for the evaluated mathematic models.

\begin{tabular}{|c|c|c|c|c|c|}
\hline Mathematic models & Temperature $\left({ }^{\circ} \mathrm{C}\right)$ & $\mathrm{R}^{2}$ & SE & $x^{2}$ & Dist \\
\hline & 20 & 0.95 & 0.2597 & 0.0025 & $T^{*}$ \\
\hline \multirow{2}{*}{ Diffusuion approximation } & 40 & 0.99 & 0.0950 & 0.0010 & $A^{* *}$ \\
\hline & 60 & 0.99 & 0.0999 & 0.0015 & $\mathrm{~T}$ \\
\hline \multirow{3}{*}{ Two terms } & 20 & 0.96 & 0.2356 & 0.0019 & $\mathrm{~T}$ \\
\hline & 40 & 0.99 & 0.0993 & 0.0010 & $A$ \\
\hline & 60 & 0.97 & 0.1521 & 0.0044 & $\mathrm{~T}$ \\
\hline \multirow{3}{*}{ Exponential of two terms } & 20 & 0.85 & 0.4756 & 0.0073 & $\mathrm{~T}$ \\
\hline & 40 & 0.97 & 0.7934 & 0.0029 & $\mathrm{~T}$ \\
\hline & 60 & 0.99 & 0.2338 & 0.0009 & A \\
\hline \multirow{3}{*}{ Modified Henderson and Pabis } & 20 & 0.96 & 0.1476 & 0.0019 & $\bar{A}$ \\
\hline & 40 & 0.99 & 0.0993 & 0.0010 & A \\
\hline & 60 & 0.99 & 0.0738 & 0.0009 & A \\
\hline \multirow{3}{*}{ Logarithm } & 20 & 0.95 & 0.2612 & 0.0025 & $\bar{A}$ \\
\hline & 40 & 0.99 & 0.0993 & 0.0010 & A \\
\hline & 60 & 0.99 & 0.0738 & 0.0009 & A \\
\hline \multirow{3}{*}{ Newton } & 20 & 0.78 & 0.5792 & 0.0109 & $T$ \\
\hline & 40 & 0.96 & 0.1836 & 0.0046 & $\mathrm{~T}$ \\
\hline & 60 & 0.99 & 0.0999 & 0.0015 & $\mathrm{~T}$ \\
\hline
\end{tabular}

${ }^{*}$ Biased distribution of residues; ${ }^{* *}$ Randon distribution of residues.

a

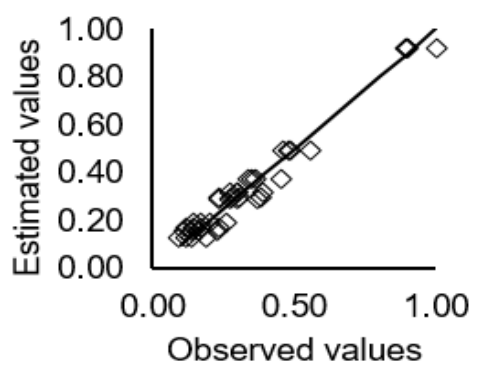

b

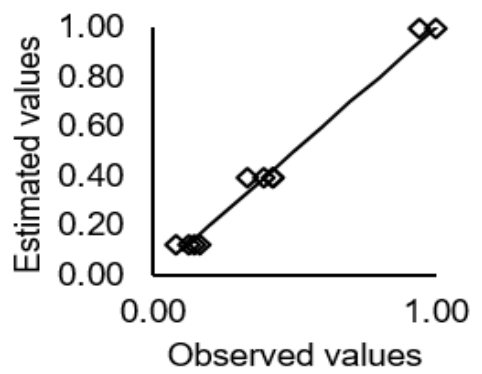

c

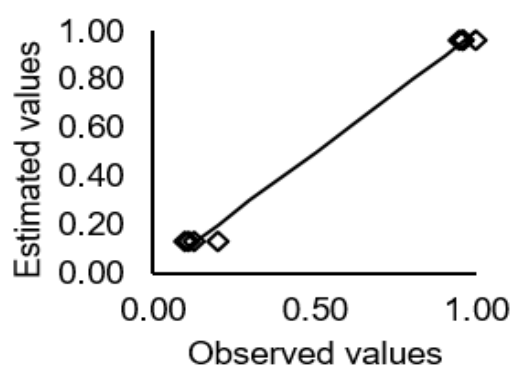

Figure 1 - Residues estimated by the Modified Henderson and Pabis model for boldo leaves at the drying air temperatures of $20^{\circ} \mathrm{C}(\mathrm{a}), 40^{\circ} \mathrm{C}(\mathrm{b}), 60^{\circ} \mathrm{C}(\mathrm{c})$.

a

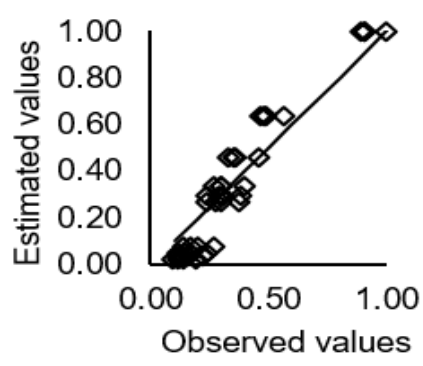

b

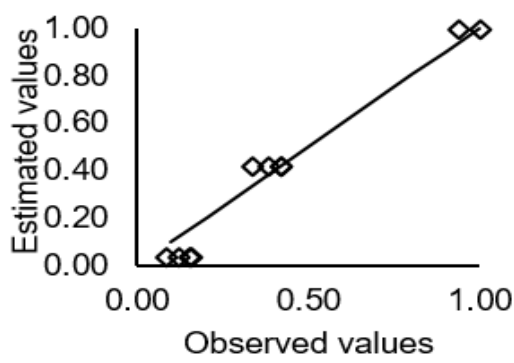

C

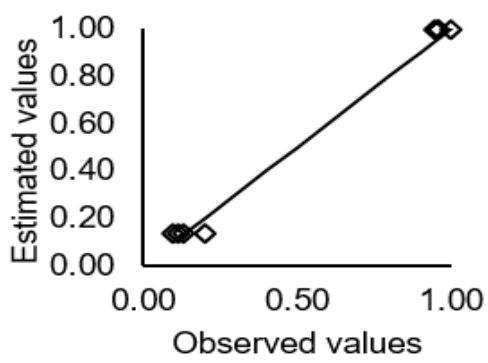

Figure 2 - Residues estimated by the newton model for the boldo leaves at the drying air temperatures of $20^{\circ} \mathrm{C}(\mathrm{a}), 40^{\circ} \mathrm{C}(\mathrm{b}), 60^{\circ} \mathrm{C}(\mathrm{c})$. 
Table 3 - Parameters of Modified Henderson and Pabis model for temperatures of drying of the boldo leaves.

\begin{tabular}{ccccccc}
\hline \multirow{2}{*}{ Temperature $\left({ }^{\circ} \mathrm{C}\right)$} & \multicolumn{2}{c}{ Parameters of Modified Henderson and Pabis model } & \\
\cline { 2 - 7 } & $\mathrm{a}$ & $\mathrm{k}$ & $\mathrm{b}$ & $\mathrm{k} 1$ & $\mathrm{c}$ & $\mathrm{k} 2$ \\
\hline 20 & $-0.1382^{*}$ & $35.0000^{*}$ & $0.6308^{*}$ & $0.4113^{*}$ & $0.4310^{*}$ & $0.0345^{\star}$ \\
40 & $0.4272^{*}$ & $35.1871^{*}$ & $0.3551^{*}$ & $0.3791^{*}$ & $0.2105^{\star}$ & $0.3477^{\star}$ \\
60 & $0.3966^{*}$ & $1.8129^{*}$ & $0.2810^{*}$ & $2.0457^{*}$ & $0.2882^{*}$ & $2.1547^{\star}$ \\
\hline
\end{tabular}

${ }^{*}$ Significant to $5 \%$ probability by t test. a, k, b, k1, c, e k2 - coefficients of the adjusted Modified Henderson and Pabis models.

Figure 3 shows the drying curves for boldo leaves at the temperatures studied, fitted for the Modified Henderson and Pabis model. It can be verified that the drying period of the samples decreases with increasing drying air temperature. This fact was also observed by Goneli et al. (2014b), who evalu- ated the drying kinetics of "erva baleeira" leaves, indicating that a decreased drying time with increasing temperatures can be explained due to an increased vapor pressure gradient between the drying air and the air inside the leaves.

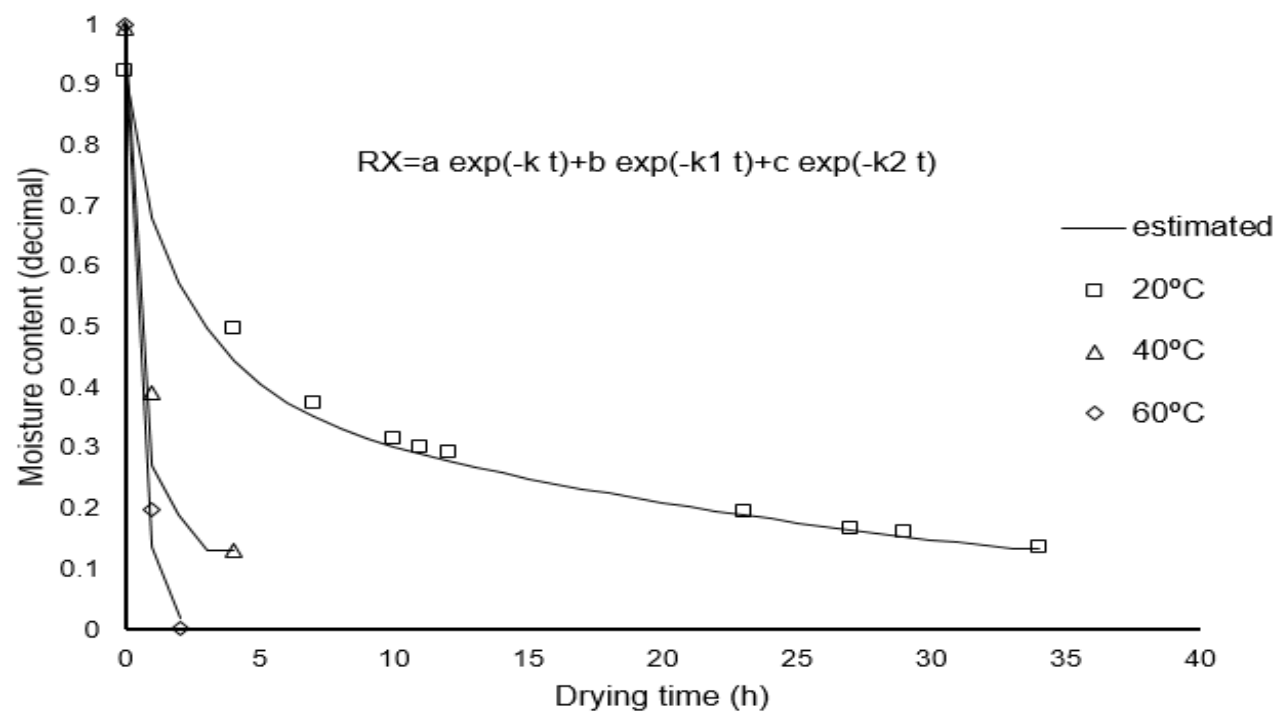

Figure 3 - Drying curve of boldo leaves adjusted to the Modified Henderson and Pabis as function of temperatures.

The activation energy for obtaining equilibrium water content was $17.96 \mathrm{~kJ} \mathrm{~mol}^{-1}$. This value was lower than that found for the drying of "erva baleeira" leaves, which presented an activation energy of $62.89 \mathrm{~kJ} \mathrm{~mol}^{-1}$ (Goneli et al., 2014a); basil leaves, with an activation energy of $70.79 \mathrm{~kJ} \mathrm{~mol}^{-1}$ (Reis et al., 2012); and "timbó" leaves, with an energy of $81.39 \mathrm{~kJ} \mathrm{~mol}^{-1}$ (Martins et al., 2015). In drying processes, the lower the activation energy, the greater the water diffusivity in the product, i.e., the less energy required for physical transformation (in this case, the transformation of free water into vapor) (Jangam et al., 2010).

Effective diffusivity values were $2.91410^{-8}$; $1.9910^{-8} ; 1.7610^{-8} ; 1.5710^{-8}$; and $1.1810^{-8}$, respectively, for the temperatures of $20 ; 30 ; 40 ; 50$; and $60^{\circ} \mathrm{C}$. It is observed (Figure 4) that the diffusion coefficient showed a trend of increase with increasing temperatures. This fact is expected, since by raising the temperature, the water viscosity decreases (Corrêa et al., 2010).

Considering thermodynamic properties (spe- cific enthalpy, specific entropy, and Gibbs free energy), the enthalpy values decrease with increasing temperature values (Table 4). Thus, at higher temperatures, a smaller amount of specific energy is required for drying to occur. As for entropy (Table 4), a similar behavior is observed, that is, the entropy reduced with increasing temperatures. Negative entropy values were attributed to chemical adsorption and/or structural modifications of the adsorbent (Moreira et al., 2008).

Gibbs free energy increased with increasing temperatures (Table 4), and the values were positive, indicating that drying was not spontaneous under the conditions of the present work. The positive value of Gibbs free energy characterizes an endergonic reaction, requiring an addition of energy from the medium in which the product is involved for the reaction to occur. This behavior is expected, since the desorption process is not spontaneous (Corrêa et al., 2010). The values found were $147.5697 \mathrm{~kJ} \mathrm{~mol}^{-1} ; 156.5880 \mathrm{~kJ} \mathrm{~mol}^{-1}$; and $165.6169 \mathrm{~kJ} \mathrm{~mol}^{-1}$, respectively, at temperatures of 20; 40 ; and $60^{\circ} \mathrm{C}$. 


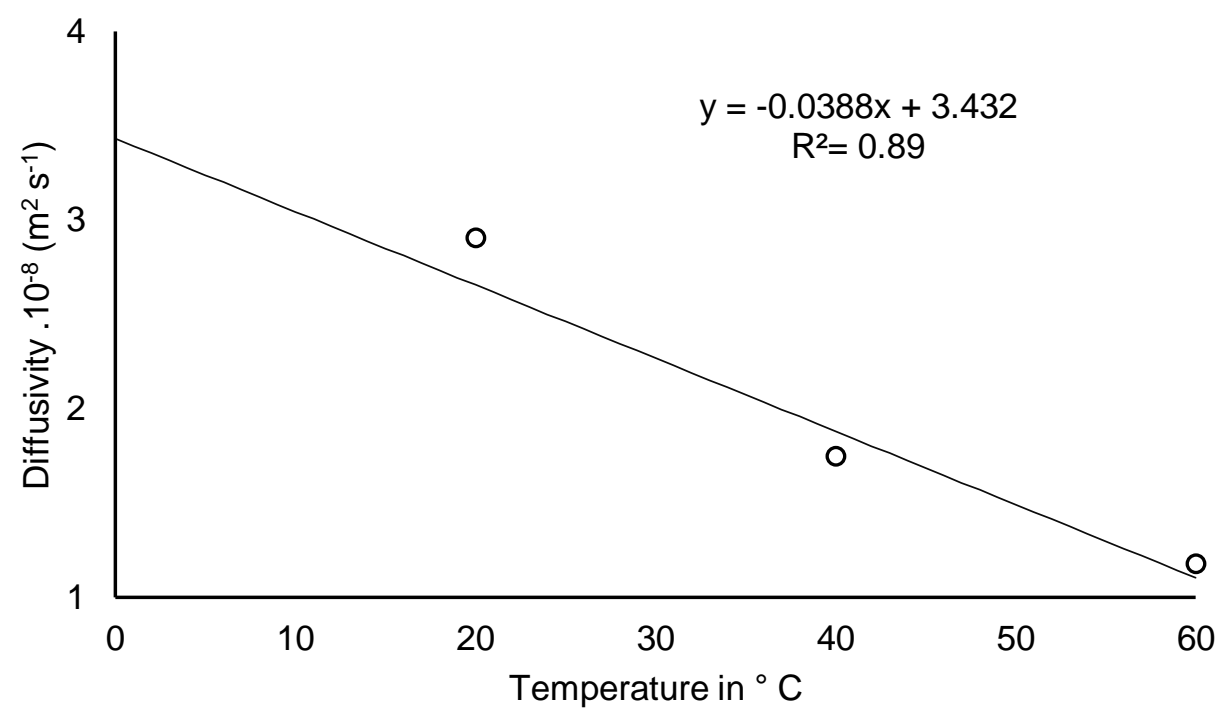

Figure 4 - Average values of effective diffusion coefficient $\left(\mathrm{m}^{2} \mathrm{~s}^{-1}\right)$ obtained for the drying of boldo leaves at three temperatures $\left(20,40\right.$ and $\left.60^{\circ} \mathrm{C}\right)$.

Table 4 - Thermodinamic properties of the boldo leaves drying process: specfic enthalpy $(\Delta h)$, specific entropy $(\Delta \mathrm{s})$ and Gibbs free energy $(\Delta \mathrm{G})$.

\begin{tabular}{lccc}
\hline Temperature $\left({ }^{\circ} \mathrm{C}\right)$ & $\begin{array}{c}\Delta \mathrm{h} \\
\left(\mathrm{kJ} \mathrm{mol}^{-1}\right)\end{array}$ & $\begin{array}{c}\Delta \mathrm{s} \\
\left(\mathrm{kJ} \mathrm{mol}^{-1} \mathrm{~K}^{-1}\right)\end{array}$ & $\begin{array}{c}\Delta \mathrm{G} \\
\left(\mathrm{kJ} \mathrm{mol}^{-1}\right)\end{array}$ \\
\hline 20 & 15.5329 & -0.4506 & 147.5696 \\
40 & 15.3667 & -0.4511 & 156.5879 \\
60 & 15.2004 & -0.4517 & 165.6169 \\
\hline
\end{tabular}

\section{Conclusions}

The Modified Henderson and Pabis model, used to characterize drying, was the one that best represented the drying process of boldo leaves.

Diffusivity decreases with increasing temperatures, showing values between $2.9110^{-8}$ and $1.1810^{-8} \mathrm{~m}^{2} \mathrm{~s}^{-1}$, for the temperature range of 20 to $60^{\circ} \mathrm{C}$, indicating that the drying in the conditions of the present work was not spontaneous.

Enthalpy decreases with increasing temperatures, while Gibbs free energy increases, being positive under the conditions of the present work. Entropy, in turn, is negative in the conditions studied in this work.

\section{References}

Araujo WD, Goneli ALD, Corrêa PC, Filho CPH, Martins, EAS (2017) Modelagem matemática da secagem dos frutos de amendoim em camada delgada. Revista Ciência Agronômica 48(3): 448-457

ASABE (2010) Moisture Measurement - Forages: Standard S358.2 DEC1988, R2008. In: American Society of Agricultural and Biological Engineers (Ed.). Standards, Engineering Practices, and Data. St. Joseph: ASABE, 684-685p
Corrêa PC, Oliveira GHH, Botelho FM, Goneli ALD, Carvalho FM (2010) Modelagem matemática e determinação das propriedades termodinâmicas do café (Coffea arabica L.) durante o processo de secagem. Revista Ceres 57(5): 595-601

Goneli ALD, Nasu AK, Gancedo R, Araújo WD, Sarath KLL (2014a) Cinética de secagem de folhas de erva baleeira (Cordia verbenacea DC.). Revista Brasileira de Plantas Medicinais 48(2): 434-443

Goneli ALD; Vieira MDC; Vilhasanti HDCB, Goncalves AA (2014b) Modelagem matemática e difusividade efetiva de folhas de aroeira durante a secagem1. Pesquisa Agropecuária Tropical 44(1): 56-64

Grandi TSM, Trindade JA, Pinto MJF, Ferreira LL, Catella AC (1989) Plantas medicinais de Minas Gerais. Acta Botanica Brasilica 3(2): 185 -224

Jangam SV, Law CL, Mujumdar (2010) Drying of fodds, vegetables and fruits, National University of Singapore. 232p

ideani VA, Mpotokwana ASM (2009) Modeling of water absorption of Botswana bambara varieties using Peleg's equation. Journal of Food Engineering 92(2): 182-188

Lorenzi HE, Matos, FDA (2002) Plantas medicinais no Brasil/ Nativas e exóticas, Instituto Plantarum. 512 p. 
Madamba PS, Driscoll RH, Buckle KA (1996) The Thin-layer Drying Characteristics of Garlic Slices. Journal of Food Engineering. 29(1): 75-97 doi:htpp://dx.doi.org/10.1016/0260- 774(95)00062-3>

Martins EAS, Lage EZ, Goneli ALD, Filho CPH, Lopes JG (2015) Cinética de secagem de folhas de timbó (Serjania marginata Casar). Revista Brasileira de Engenharia Agrícola e Ambiental. 19(3): 238-244

Martins ER, Castro DM, Castellani DC, Dias JE (2000) Plantas medicinais.UFV. 220p.

Moreira R, Chenlo F, Torres MD, Vallejo N (2008) Thermodynamic analysis of experimental sorption isotherms of loquat and quince fruits. Journal of Food Enginnering. 88(1): 514-521

Oliveira GHD, Aragão DMS, Oliveira APLRD, Silva MG, Gusmão ACA (2015) Modelagem e propriedades termodinâmicas na secagem de morangos. Brazilian Journal Of Food Technology. 18(4): 314-321

Onwude DI, Hashim N, Janius RB, Nawi NM, Abdan K (2016) Modeling the thin-layer drying of fruits and vegetables: A Review. Comprehensive Reviews in Food Science and Food Safety. 15(1): 599-618.
Reis RCD, Devilla IA, Ascheri DPR, Servulo ACO, Souza ABM (2012) Cinética de secagem de folhas de manjericão (Ocimum basilicum L.) via infravermelho. Revista Brasileira de Engenharia Agrícola e Ambiental. 16(12): 1346-1352

Resende O, Ullmann R, Siqueira VC, Chaves TH, Ferreira LU (2011) Modelagem matemática e difusividade efetiva das sementes de pinhão-manso (Jatropha curcas L.) durante a secagem. Eng. Agríc, 31(6): 1123-1135

Santos, DDC, Queiroz AJM, Figueirêdo RMFD, Oliveira ENAD (2013) Cinética de secagem de farinha de grãos residuais de urucum. Revista Brasileira de Engenharia Agrícola e Ambiental. 17(2): 223-231

Siqueira VC, Resende O, Chaves TH(2012) Drying Kinetics of Jatropha seeds. Revista Ceres. 59(1): 171177 doi: http://dx.doixorg/10.1590/S003473X20100200004

Sousa FC, Martins JJA, Rocha APT, Gomes JP, Pessoa T, Martins JN (2015) Predição de modelos sobre a cinética de secagem de folhas de Ziziphus joazeiro Mart. Revista de Plantas Medicinais. 17(2): 195-200. 